\title{
The Kapsiki Home Sacrifice
}

\author{
Walter E. A. van Beek
}

\section{Introduction: The Setting}

The Kapsiki/Higi are one of the numerous groups living in the area south of the Chad Basin, along the western edge of the Mandara Mountains straddling the border between Cameroon and Nigeria. In Cameroon they live on a plateau at 1,00o meters surrounded by mountain ridges rising to 1,300 meters. The plateau is dotted with spectacular volcanic outcroppings. On the western side in Nigeria, the Higi, as the group is called there, cultivate the mountain ridges and the plains to the west extending farther into Nigeria. Before the pax colonialis, this mountain habitat offered good protection against slave raiding, while still allowing for subsistence cultivation. After colonial rule was established, people gradually moved down from hilltops, spreading out over the plateau or into the lower river valleys.

The Kapsiki/Higi number about 200,000, the largest part living in Nigeria. ${ }^{1}$ Situated in an old volcanic area, the plateau and hillsides are quite fertile and are cultivated on a permanent basis by crop rotation and few inputs. In fact, the mountains are well suited to labor intensive horticultural production using relatively simple technology and mixed husbandry, and that is how the Kapsiki make their living. Kapsiki villages are autonomous, within the formal political structures of present-day Cameroon and Nigeria. Each village has a traditional chief with a predominantly ritual function, and consists of several wards, each with a ward chief, mainly for administrative duties. The crucial social unit is the individual compound, rhè, housing a nuclear or extended family, usually polygynous. A classic mountainside, Kapsiki compound is a veritable fortress with its man-high stone wall, a reminder of the bad old days when walls formed a last defense against marauders. And, as we shall see in the sacrifice, the wall is still important. ${ }^{2}$

1 The 2003 Cameroonian census gives 96,00o Kapsiki; Nigerian figures are less reliable, but the Higi tend to be twice as many as the Cameroonian Kapsiki. I keep the conservative estimate of 200,000, accounting for some over-reporting by censuses. See Walter E. A. van Beek, "Introduction," in Contes Kapsiki du Cameroun (ed. Walter E. A. van Beek and H. Tourneux; Paris, Karthala, 2013), pp. 7-23.

2 Oxford University Press is thanked for its kind permission to use and rework material from Walter E. A. van Beek, The Dancing Dead. Ritual and Religion among the Kapsiki/Higi of North Cameroon and Northeastern Nigeria (New York: Oxford University Press, 2012), chapter 5.

(C) WALTER E. A. VAN BEEK, 2017 | DOI 10.1163/9789004335530_003

This is an open access chapter distributed under the terms of the $\mathrm{CC} B \mathrm{BY}-\mathrm{NC}$ 4a license. $\mathrm{A}$. 


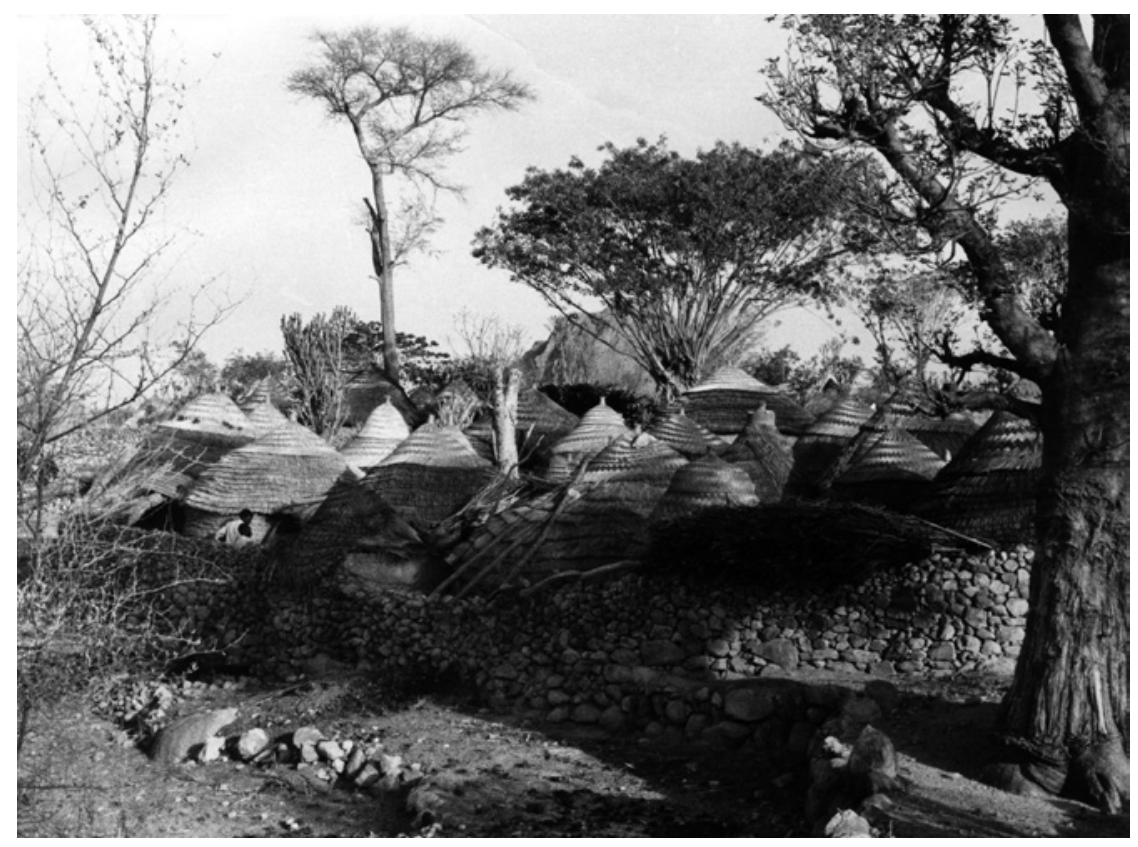

Fото 1 A Kapsiki compound from the outside.

The man-high stone wall is a center of ritual attention. Its height shields the inhabitants from view or, as the Kapsiki say, it hides their poverty. At the narrow entrance, the wall is higher and bears many traces of former sacrifices and libations. The wall effectively separates the inside from the outside, the family from the rest of the society, and kin from non-kin - distinctions resonating in the sacrifice. Outside the wall is situated the forecourt (derha), a lower structure serving as the social space of the rhè. The house as a whole is oriented more or less north-south, as neither the setting nor the rising sun are allowed to shine directly through the opening of the wall; this would be considered unhealthy.

In the dry season, most family activities and all public functions take place in the entrance court, the derha. People freely enter the forecourt, but no stranger advances through the wall at the back of the derha without very good reason. Just behind the opening in the wall is the entrance hut proper, the dabala, a round hut with two openings, where the family cooks and eats in the wet season. The inside of the compound is divided into a male and a female side. The male side houses sleeping huts for the master of the house and his sons, and the female side has huts for each of the women. If the wives want to 
have their own kitchen, they have double huts, a kitchen plus a sleeping hut, but in many families the wives share a kitchen and have just sleeping huts. Each woman has her own washing spot between her sleeping hut and the wall, with a small outlet at the base of the wall, an important ritual spot, as women bury the umbilical cords and placentas of their children here. For a man it is a dangerous place that he will not readily enter, fearing for his virility.

The layout of a typical compound is as follows:

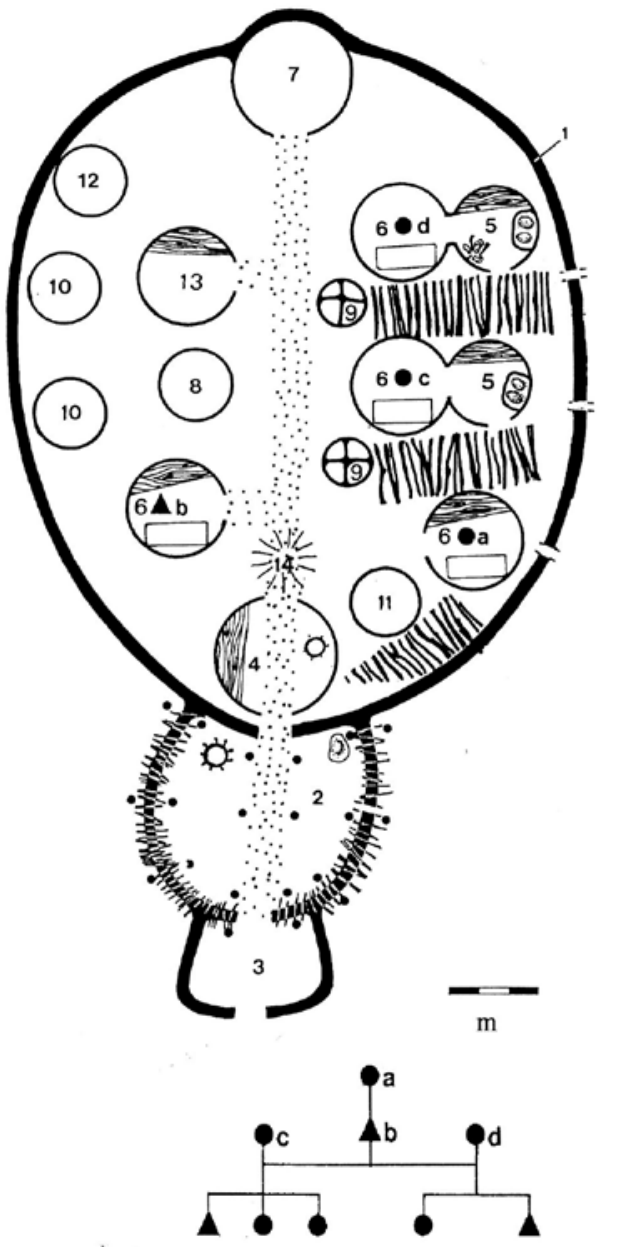

Household composition

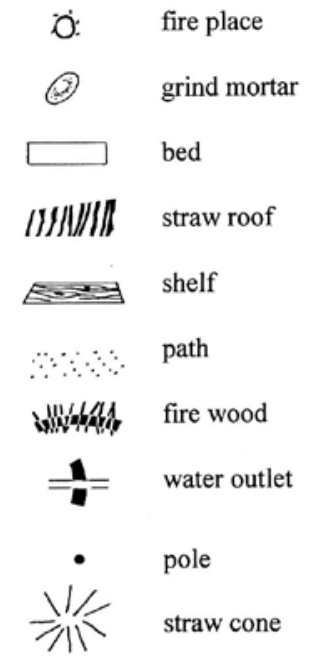

1. Wall (yindlu)

2. Forecourt (derha)

3. Second forecourt

4. Entrance hut (dabala)

5. Kitchen

6. Sleeping hut

7. Brewery

8. Plaited granary, man

9. Small crops granary, woman

10. Granary man, clay

11. Granary woman, clay

12. Goat stable

13. Empty hut 
Tlimu Vandu has consulted the crab diviner and received clear instructions about holding a melè rhè, a sacrifice in his compound, in honor of his father, Vandu Zra Tè, who had died two years before. The sacrifice is also held at the request of a close friend of his father's. ${ }^{3}$ In the evening before the sacrifice, he buys some red beer, tè, to fill his sacrificial jar. In the early morning, at half past five, he takes a red rooster which he has bought at the market for this purpose, as instructed by the diviner. His neighbors are not aware of what is happening, and because visitors are not welcome, Tlimu closes the compound entrance with a large stick: Now it is taboo to enter the compound as a stranger. Only a smith may be invited to perform the sacrifice, but that is more usual when slaughtering a goat than a chicken.

Without any ritual preparation, Tlimu takes his large sacrificial jar, called melè, from under the granary, plucks the rooster's neck (the jar has to taste the first blood), cuts it and lets the blood drip on the jar. He gently touches the jar with the dying rooster, saying:

My shala, here you have something to eat. ${ }^{4}$ Father, here is your friend, he has not forgotten you. I have not seen you for a long time and people have arrived after your burial to honor you with the tè shingli, in order for the people to be healthy, healthy after your demise.

He throws the rooster on the ground, and watches how it dies. If the dying animal flaps its wings, shala (god) has accepted the sacrifice: "Thank you, shala,

3 That, in fact, is me. I asked for this sacrifice for two reasons. Vandu Zratè was a close friend and I could not attend his funeral, which happened while I was in The Netherlands. Also, attending a sacrifice that is not one's own is difficult in Kapsiki religion, and I liked to participate in this one - a typical example - and participatory dilemma - of a close friendship that is instrumental as well.

4 Shala ta da, nde wusu kezeme ashè gè. In order not to confuse readers, I use a simplified orthography for the Kapsiki language, officially called Psekyè, in which implosive consonants are not marked.

5 The notion of shala is complex. Though increasingly used to indicate some kind of monotheistic being, it in fact is a personal god: Every Kapsiki has his or her own shala, but at a certain level they shade over into each other. See Van Beek, The Dancing Dead, chapter 6, as well as Walter E. A. van Beek, "Why things go wrong. Agency and evil among the Kapsiki of North Cameroon," in Agency and Changing World Views in Africa (eds Dieter Neubert and Christine Scherer; Berlin: LIT Verlag, 2014), 73-98. 
thank you shala". ${ }^{6}$ If not, he would be disappointed but would not repeat the sacrifice. Then Tlimu walks round the inside of the wall, counter clockwise, slapping the bloodied neck of the rooster against the wall, as a part of the ritual called kayisù yindlu (sprinkle the wall). He ends his round in the dabala, where some of his children sit around a small fire. With a glowing ember he singes the feathers of the rooster and holds it for a moment over his children's heads. With two of his sons taking the rooster's legs, Tlimu cuts off the legs and throws them into the compound - "for his father" - to be eaten later. The oldest son takes over one of his father's duties, puts some of the intestines, especially the liver, on the melè and starts roasting the chicken. The whole procedure appears a routine, 'work' as Tlimu calls it, and the children know what to do. It is done quickly, and at 6.30 am the family is in the dabala, waiting for the rooster and some mush, cooked by one of Tlimu's daughters. His whole family cannot be present as its size is spectacular (four wives and 37 children, with numerous grandchildren $)^{7}$ but the youngest are there. When the animal is roasted, Tlimu takes his melè again from under the granary, picks up a piece of the rooster's liver, some mush, and with his right hand smears the mix on the melè. He then takes a mouthful of beer from the jar and sprinkles his breast, for the mpisu $h w u$, spitting on the chest, a rite aimed at the "bad thoughts in the heart", especially bad thoughts about other people.

Shala, give me health. ${ }^{8}$ Take the evil out of my belly, make me healthy, I say. I have to hear the words from outside. Whoever is jealous, I trample under my feet. Our children, who have stayed behind, we should not be jealous. Whatever illness we have should disappear like the wind. May the illness pass because you want it. ${ }^{9}$ [Words from the 'outside' means that any news, bad news, comes from another home.]

6 Hana shala, hana shala.

7 Tlimu is a highly successful husband and father, as discussed at length in Walter E. A. van Beek, "Dynamic of Kapsiki/Higi marriage exchanges," in Les échanges et la communication dans le bassin du lac Tchad (eds Sergio Baldi and Geraud Magrin; Naples: Studi Africanistici, Serie Ciado-Sudanese 6, 2014), 105-131.

8 Yita, ndeke da lèngelèle pe 'ya. Pelu tengwela jive 'ya kafa rhena. Mpelè ya ngkede wundu nya kedema ntsu ta da mbe hwu seda.

9 Meaning that shala has to want the illness to disappear and thus has to be convinced by the speaker. 


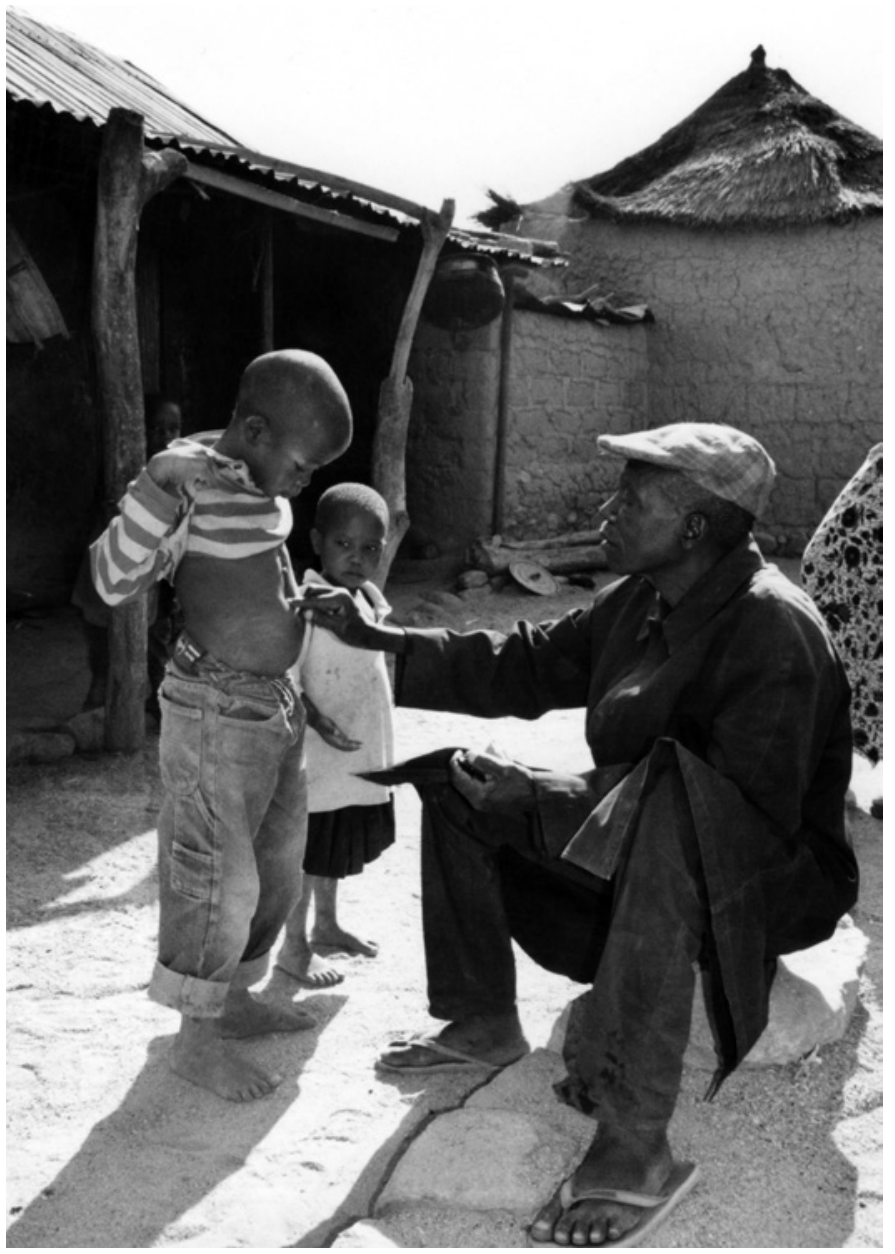

Liver on the chest of the kids.

Then one by one the children come along, and Tlimu smears liver on their chest: "Here, eat". One crying toddler gets some meat in advance, the others simply wait.

Tlimu gives each of his wives, who are watching him from their hut, some mush which they put on her own melè, a small jarinside their hut. They have been discussing among them whether the whole family had to be called in, as far as feasible, or whether just the present kids were sufficient for the sacrifice. After some debate they decided that it was not a melè keshi, a lineage sacrifice, which the mention of their father-in-law might suggest, but indeed a melè rhè, house sacrifice. So just the ones present would do. Tlimu pours beer from the melè 
in an plain white calabash (it should be a traditional oblong calabash, but he has none) and then one of the high points of the sacrifice follows batle melè, inundate the jar:

This is for you, Vandu, because your friendship has to be fresh, everybody has to be fresh after your death. Shala, let the wind take whatever is evil. Please have them return safely to their villages, for them to visit us again.

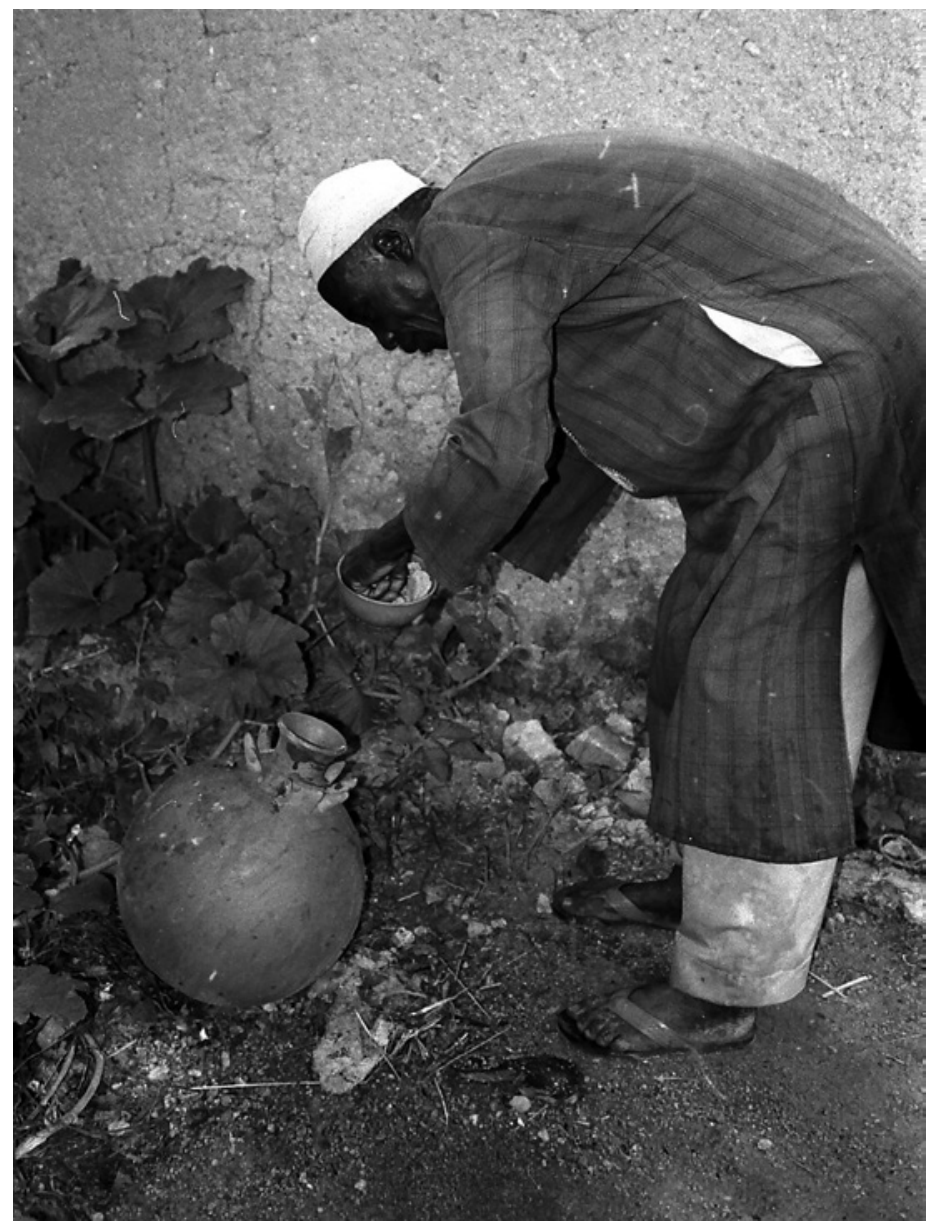

Tlimu sacrificing on his melè. 
In the meantime a neighboring smith woman has come into the house - which is her right - as her presence enhances the status of the ritual. She loudly ululates and praises Tlimu for his work in keeping the house in order. Later her husband joins Tlimu in drinking from the melè; he has assisted Tlimu in building a hut, and now brings some rice from his daughter's wedding for everyone to taste. ${ }^{10}$ A young son of Tlimu drinks first and the family gathers to drink the beer, the men around the melè, and the women in front of their own huts with the smith woman. When the beer in the melè is almost finished, Tlimu calls the men to witness the mekele melè (lifting the jar); they all watch Tlimu tilt the jar upside down to empty it, the end of the sacrifice proper, and the oldest of the men, his father's friend drinks first of this last calabash. Finally, Tlimu puts the meat and mush in his personal vase and all finish the beer and eat, clapping their hands to thank shala.

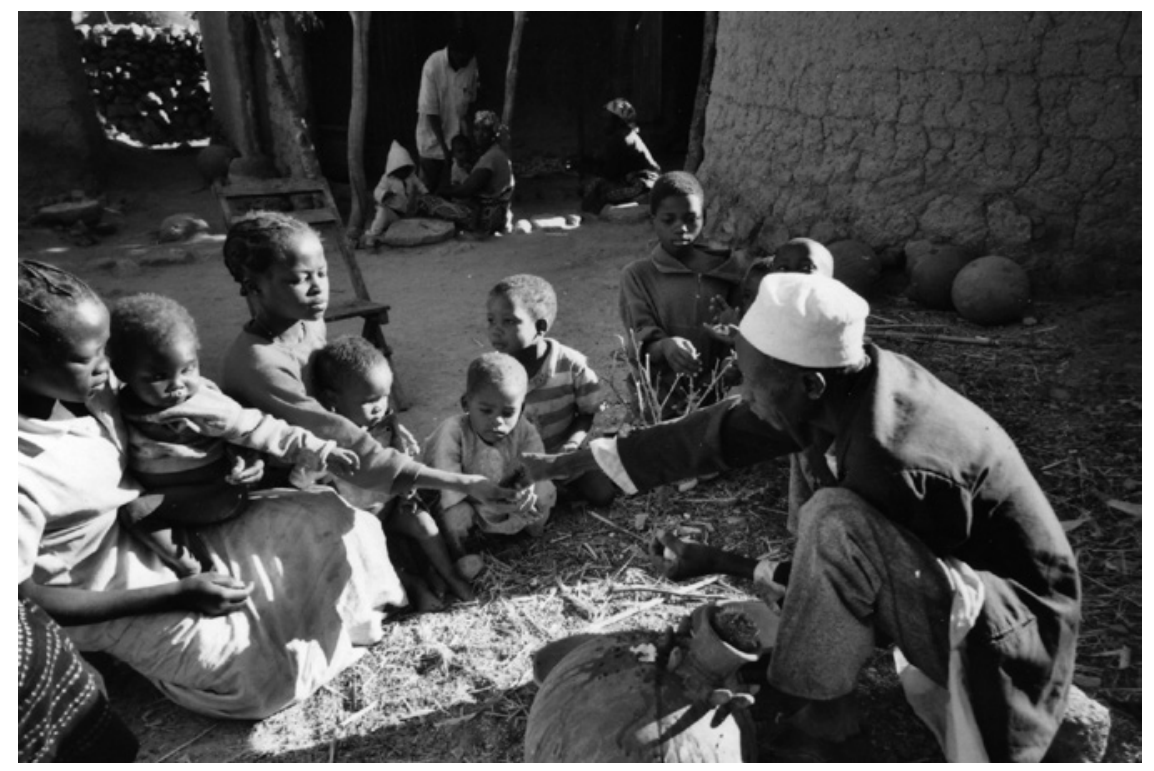

Tlimu hands out the sacrifice to some of his children at the end of the sacrifice.

10 Smiths form a special category of people in Kapsiki society. The men forge, divine, bury, make music or medicate, while their women make pottery and are specialized in treating children's illnesses. Smiths, rerhè in Psekyè, are so by birth, marry among themselves, thus forming an endogamous echelon with a lower social status than the melu, the common Kapsiki. Smiths of both genders are welcome at melu sacrifices, due to their position as intermediaries between this existence and the "other world". Cp. more general, Mircea Eliade, Schmiede und Alchemisten, (Stuttgart: Ernst Klett Verlag 1956). 
Now that the first part of the sacrifice is over, the beam shutting the entrance is removed so neighbors are welcome once more. In the evening, the rooster is cooked as part of the evening meal. Then Tlimu takes some of the liver from the cooking pot with sorghum mush and puts the mix on the jar, which is back at its resting place under the granary: "Here, father, some food for you. Give me health, take the illness away".11 The family then eats the mush and the rest of the rooster.

\section{The Sacrificial Jar}

The central object in the sacrifice is the melè, the sacrificial jar, a piece of pottery shaped like a standard beer jar but for a few symbols: It has a ring of small clay cones around the neck and a symbolic indication of the male or the female sex. Closed with a cow's horn, its usual resting place is under a granary. The women keep theirs inside their own huts. Both parents can be represented in such a jar, and an individual can also have a special melè as circumstances dictate. One special type is the gumeze, a jar with a threefold neck with one opening. A man has this kind of melè made if he has killed someone in battle or if he has killed a special kind of bird. Killing this particular bird brings bad luck, like the death of a child, unless he has such a gumeze. If he killed someone in war, two jars are made, one large, one small. The small one receives the name of the victim and is buried in a field, while the larger one is used for sacrifices. The small one is dangerous and is not actually used; in his final spoken will, the owner of a gumeze has to tell his son where he has hidden the small jar. He is to break it when his father dies.

Another kind is called after the sun, veci, and looks just like a normal jar, so without any symbols. It is an exacting jar to own. Anyone who rises very early may see the sun at the horizon in the shape of a ram, ascending into heaven at sunrise. Viewing such a ram implies that it will rain in the morning, and the ram signifies the transition from moon to sun. In such a case it is wise to perform divination to ascertain who has to make the jar, who can drink from it and who cannot, and whether it has to be hidden. Such a veci demands many sacrifices, which can be a source of pride, if one is able to perform all those sacrifices.

A sacrificial jar is made at the death of a parent. Before that time a man has another type of melè, usually a flint stone the size of a fist, whereas a woman has just a small jar. A boy gets his flint from his father, a girl from her mother;

11 Nde nganga wusu kezeme, yita. Ndeke da lèngèlènge, kelemte zererhwe nya kiku. 
during initiation a boy gets his first proper melè, while a girl uses a small jar as mèle presented during their first wedding ${ }^{12}$ and given by her groom. Smith women fabricate the melè, like all pottery. So after the death of his father a son orders one. When the mèle is ready, the blacksmith woman takes a fistful of sorghum flour, mixes it with water and pours the mix on the jar with the words: "Let everyone be healthy", which is also called batle melè, in fact a sacrifice in itself. Later the son gives her a huge bowl of millet flour; if he forgets it, she will harass him at his home, telling him that she is "so very hungry". She also has to be invited at the first use of the jar, after the funeral rites, when it is inaugurated as a real melè, that is, as the representation of the parent. During the sacrifice, the melè is addressed as 'father' or 'mother'. The jars serve only the direct descendants, as a personal melè is destroyed during one's funeral rites. Therefore the melè can never represent a grandfather.

A melè proper, with the cones plus the genital decoration like Tlimu's, is only for one son, the oldest firstborn son of one of the deceased's wives, if possible his first bride. Other brothers, like the firstborn sons of other wives, have a veci made, and so have the younger brothers, just a smaller jar. This veci has no danger element. When they sacrifice on it, they do not call on their 'father' but on shala, god, as the connection with their father is through the proper melè only. If there is no son, the oldest daughter will take the melè. ${ }^{13}$

4 Varieties of Sacrifice

There are several types of home sacrifices. The one just described is, in principle, just for the family, often generated by a problem and indicated by divination. More extensive home sacrifices, as we shall see, involve sacrificing a goat. But sometimes a quicker procedure is used, with a simple mix of sorghum flour with water. Most of the mixture is put on the entrance in the wall, the mè pelu.

12 Kapsiki marriage is unstable, and most women have more grooms, consecutively, the main theme of Walter E. A. van Beek, The Kapsiki of the Mandara Mountains (Prospect Heights: Waveland Press, 1987). The first marriage of a girl is a large ritual event, her eventual secondary marriages are much less ritualized.

13 When people convert to Christianity or Islam, these jars are the first things they leave behind, being the icons of the traditional religion; this holds not just for the Kapsiki, but also for other mountain cultures, such as the Mafa, their northern neighbors. See José van Santen, They leave their jars behind: the conversion of Mafa women to Islam (Leiden: venA, 1993). 
Other types of sacrifices are classified depending on the social echelons of the village: A lineage sacrifice, a ward sacrifice, and the most important one, the village sacrifice. ${ }^{14}$ Any sacrifice consists of four essential elements: Slaughtering the animal, pouring upon the jar, spraying the belly, and putting food on the jar.

Though divination ${ }^{15}$ does give directions for the sacrifice, the variation rests in the detail: Who is allowed to be present, the color of the sacrificial animal, whether a blacksmith performs the ritual and any special words to be said. The format can be found in sacrifices at any social level. One common element in all sacrifices is chasing away "bad things" or "bad thoughts", which are not defined in any greater detail but are ubiquitous. Evil has to leave, has to go to someone else; it has to be elsewhere, not here. Some evil is inevitable, so someone who should suffer, is possibly someone else.

The home sacrifice has also a larger variant, reaching beyond the confines of the compound. When the reason for the sacrifice is more important, that is, when social problems indicate a sacrifice, a goat has to be slaughtered. Yet the main difference is not the animal but beer. When a goat is sacrificed, the man has to brew the ritual beer of the Kapsiki, ${ }^{16}$ which provides the time frame for the major rituals in Kapsiki. The recipe for brewing beer is similar all over the world. One soaks sorghum grains in water for a day, and lets them sprout and dry. Sprouts in Kapsiki should not remain exposed to the air too long, because otherwise "the beer is for one's one burial". ${ }^{17}$ The brewing process includes a long cooking period, a day and a night, and then the beer is taken from the large cooking pot into beer jars, including the melè. For ritual beer, the brewer does not add yeast but he simply waits three days for the beer to ferment on its own. After the second day, the beer starts to ferment and is called sarerhè

14 A special sacrifice in these Mandara Mountains involves the largest of all sacrificial animals, a bull hand-fed in the stable. This complicated sacrifice bears some quite distinct characteristics. See for the North of the Manadara area, Charlotte von Graffenried, Das Jahr des Stieres: Ein Opferritual der Zulgo und Gemjek in Nordkamerun (Studia Ethnographica Friburgensia 2, Freiburg: Freiburg Universitäts Verlag, 1984). For the Kapsiki variant, see Van Beek, Dancing Dead, chapter 5 .

15 Usually with a crab. See Walter E. A. van Beek, The Smith in Kapsiki/Higi Culture, North Cameroon and Northeastern Nigeria (East Lansing: Michigan State University Press, 2015), in press.

16 Walter E. A. van Beek, "Kapsiki Beer Dynamics," in Ressources vivrières et choix alimentaires dans le bassin du lac Chad (eds Eric Garine, Olivier Langlois and Claude Raimond; Paris: IRD, 2006), 477-500.

17 The crux of the brewing process, viz. sprouting the sorghum, in effect is the very reason these people are called Kapsiki: psekè means to sprout. 
(the smith drinks), and then it will be used for sacrifice. ${ }^{18}$ The sacrifice follows the same general liturgy as the sacrifice of a chicken, but spitting on the belly and putting ground millet on the melè is only done if the diviner has specifically indicated the need to do so.

The man and his son keep the goat's neck above the jar, and the father stabs it to let the first blood fall on the melè. Everybody listens to the man praying "Shala, let us all be healthy, here is something to eat". The man cuts the throat of the animal, the blood is collected in a pot, and all who live in the compound put some of it on their own melè. With the goat dead, beer is poured in a special oblong calabash and the owner pours on his melè, asking for health, children and good feelings in the house and the ward. His son gives all people of the family some beer for their personal melè, and the man pours blood and beer on the entrance of the wall, putting some blood and beer every few meters on the inside of the wall. Finally, he pours blood and beer in the hollow stone at the lower end of the forecourt. He is the first then to drink, and his wives and children follow him, spraying beer on their bellies and putting the food stuff on their belly as well, as we saw in the sacrifice of a chicken. The goat is skinned, butchered and cooked, and life in the compound resumes it normal daily rhythm. In the evening, the rest of the meat is cooked as part of the sauce. The owner then takes the broiled liver from the pot and, with both hands, puts a few morsels and some excrement on the melè, with similar word. His family does the same.

One may invite a sister's son as a special guest. While a nephew performs the actual slaughter on normal occasions, he does not do so for sacrifice, but his presence will add to the well-being at the sacrifice. The link between mother's brother and sister's son in Kapsiki is close and affectionate and this task is deemed fitting. After a non-ritual slaughter the boy will get a substantial amount of meat, the neck, liver, first stomach (omasum) and a piece of a hind leg. All this precious meat he will bring home proudly, to eat with his family.

The main difference between a chicken and a goat sacrifice can be seen early the next morning. In case of a goat, close kinsmen and invited neighbors assemble for the last phase of the ritual, drinking from the tè melè. The beer now has its optimal level of fermentation. In such a ritual drinking spree, the owner carefully distributes a number of beer jars, one for the old men around the fire place, one for some other guests, while the melè itself remains in the

18 The Kapsiki also know a white beer variant that is brewed exclusively by women for immediate consumption or for the market. Recently, the women have taken up brewing the red tè for the market, developing a quicker process enhancing the taste. 
house for the immediate kin. Then he explains the reason for the sacrifice in often extremely vague, even elliptical language:

I was at somebody's who dreamt that I had to do a sacrifice, a few nights ago. I have put some grains in the water and on the melè. I have something left and invited a few people to drink together with me.

He indicates no specific problems, just the fact that he 'dreamt', that is, consulted the diviner and has prepared beer. But the neighbors probably know the reasons anyway, as such a sacrifice is aimed at "usual problems" like illness or infertility, though it also might be held at more regular intervals to keep the house healthy.

The owner himself drinks first, while his family drinks from the melè inside the house. The old men applaud the owner and the oldest or the village chief offers flattering comments. He should do that also in the favored Kapsiki speech style, in which a lot is said with as little clarity as possible. Hyperbole, hidden references to happenings in the past, and parts of stories are mixed into a discourse which is real "inside speak". "Some grains in the water" is quite an understatement because between 80 and 120 liters of beer is standard, and this ritual drinking takes all morning.

A house owner may invite a blacksmith, either at his own wish or because divination has told him to. In that case the smith sits at the side, softly clapping his hands; if the sacrifice is done in the evening, the smith may perform the sacrifice, but it will be something small, like a chicken. For some serious issues, a sacrifice will take place outside home, for example at a spot associated with shala (god) in the bush; in that case a blacksmith has to do it, as it would simply be too dangerous to do it oneself. For such a sacrifice the color of the goat is clearly indicated, usually black, and the animal is left in the bush; sometimes its feet are broken and then it is left behind. In a few cases the blacksmith may take some of the immolated beast back home, depending on the divination. Reasons for such intense sacrifices are, for example, a child's death or prolonged infertility.

The general mood during a sacrifice is usually quite relaxed. The ritual does not call for a reverential attitude or for special outfits; Kapsiki ritual is often quite homely, part of everyday life, without specific formulas or attitudes. Only in rituals for the whole village, such as the village sacrifice, is the whole day marked off as a day-out-of-time, as a liminal day and then nobody should cultivate. The transition from daily time to ritual or liminal time is usually not marked, and is gradual and smooth; yet there is a recognizable core to the ritual, a symbolic focus, which defines the high point of the proceedings. 
In sacrifice, this is the killing of the chicken, although the prayers and blessings during a sacrifice are straightforward and in normal language.

\section{Discussion}

Sacrifice has received much theoretical attention since the start of religious studies and anthropology. Not only is sacrifice the core rite in Kapsiki religion, this is the case in many religions throughout the world, and with good reason. Sacrifices come 'naturally' in religions; in the past they have been characterized as bribe (E. B. Tylor), as gifts to the gods (M. Mauss), as acts of consensual violence (R. Girard) and throughout as communion with the sacred. But if anything characterizes the Kapsiki sacrifice it is the notion of a meal, a family meal; the classic scholar of religion Robertson Smith would recognize this immediately. It is in many respects a standard family meal, but for the presence of the unseen, of a family member who is dead - the father - or of a special guest who is invisible, in this case shala. In the terminology of the new cognitive theory of religion, ${ }^{19}$ such a sacrifice is a cognitively optimal ritual, a ritual that comes quickly to mind, is easily remembered and has a liturgy that does not require a good memory, as it is just a normal meal with an invisible guest.

The core notion here is "minimal counterintuitive", a term coined by Pascal Boyer for supernatural concepts. Supernatural beings are conform our inbred expectations of human beings but with one single but significant change: A ghost is a person, but without a material body; a witch is a normal embodied person with a spirit that detaches itself and can do harm; a god is a being like a person with some special power of omnipresence. ${ }^{20}$ The power of these concepts is that they fit in well with our existent cognitive framework, but through their one minor-but-crucial difference stick to the memory. They are quick to learn, easy to transmit and hard to forget. I think that this productive concept can well be used for rituals too. Concepts that are minimally counterintuitive are called cognitively optimal, and hence rituals that are minimally counterintuitive I will call optimal rituals. ${ }^{21}$

Such a meal becomes an optimal ritual because of one minimally counterintuitive aspect, the invisible guests. They are human, addressed yes, fed

19 Harvey Whitehouse, Modes of religiosity. A Cognitive Theory of Religious Transmission (Oxford: Altamira Press, 2004).

20 Pascal Boyer, Religion explained: The Human Instincts that fashion Gods, Spirits and Ancestors (London: Vintage Books, 2002).

21 Whitehouse, Modes, chapter 4. 
definitely, personally known without a doubt, but nobody sees them and they digest nothing. As one eats every day in almost the same way, the exegesis remains close to home: Eating with the 'other'. The model for the optimal ritual is a daily event, ordinary, normal and not easy to forget. In a similar vein, in one of the few gestures that are out of the ordinary in the home sacrifice, the children get their first food on their belly instead of inside them. When Tlimu put the stripes of mush on his children's belly, the act in itself was cognitively optimal. Feeding the belly is normal, feeding the belly on the outside is minimally counterintuitive, an optimal ritual act. ${ }^{22}$

The minimal counterintuitive aspects are in the unseen presences and in the act as slight but crucial departures of the normal meal, but are also represented materially, in the melè itself. The jar represents the conceptual beings plus the different way of eating. So the counterintuitive aspect is not only thought and done, but also embodied, a special object stored at a special place, to be used and addressed only at this occasion. Although some melè are recognizable as special pots, many in fact have no distinctive features. A jar is a melè thanks to its history: It was fabricated as a melè, has functioned as such in the rites of farewell for the father, and simply is considered special. ${ }^{23}$ That unseen presence has a clear material focus in the sacrificial jar, the melè, but also in the wall of the house, which renders the unseen less invisible after all. ${ }^{24}$ Thus there are not only minimally counterintuitive concepts and rituals, but also

22 This closeness to everyday experience also enhances the self-referential function of ritual, in the words of Rappaport, implying a self-contained act in which the actors have a definite position, but where the basic and overly clear message is that people are inside a ritual. Roy A. Rappaport, Ritual and Religion in the making of Humanity (Cambridge: Cambridge University Press, 1999).

23 Pots are usually used for shrines in this region: Judy Sterner and Nicholas David, "Pots, stones and potsherds: Shrines in the Mandara Mountains (North Cameroon and Northeastern Nigeria)," in Shrines in Africa; History, Politics and Society (ed. Allan C. Dawson; Calgary: University of Calgary Press, 2009), 1-40. The notion that pots are people, as argued for the Bulahay and Mafa to the North of the Kapsiki, does not hold for the Kapsiki, at least not nearly so strong: Nicholas David, Judy Sterner \& Kondji Gavua, "Why Pots are Decorated," Current Anthropology 29, 3 (1988): 265-289. Compare the Mofu situation, Jeanne-Françoise Vincent, "Le prince et le sacrifice: pouvoir, religion et magie dans les montagnes du Nord-Cameroun," Journal de la Société des Africanistes 2 (1987): 89-121, as well with other West African types of shrines, Walter E. A. van Beek, "Shrines and sacred places in two traditional West African religions," in Sacred Spaces and Contested Identities (eds Paul Post, Philip Nel and Walter van Beek; Trenton: Africa World Press), 65-82.

24 For a treatise on the cognitive weight of the various senses in Kapsiki, see Walter E. A. van Beek, "Eyes on top. Culture and the Weight of the Senses," in Invisible Africa; Sprache und Geschichte in Afrika 21 (ed. Anne Storch; Köln: Koppe, 2010), 245-270. 
objects. This sacrificial complex is, as an optimal ritual, what I would call with Whitehouse an "attractor point": A series of minor changes in the daily routine and entourage, constituting a rite in which people can feel at home, can do almost as they are wont to do and yet feel connected with the other world.

This cognitively optimal characteristic is highlighted by, for instance, the absence of formulaic speech. People tell shala or their father directly what they want, and this entails just the basics of life: Food, health, fertility and reasonable relations. And please no evil, not here in this compound at least. The unseen presence is addressed in terms of reciprocity:

We give you food, so give us health, or even the reverse, if you do not give us ours, then you can forget about any claims upon us. If you let us suffer, you will suffer as well.

And what could be more cognitively optimal than reciprocity? Both the visible and the unseen are joined at the hip, interdependent in one fragile universe. For the rest, nothing special there, and thus sacrifice is in a way "nothing special", it is just doing what comes naturally. 